\title{
単結晶 $\mathrm{MnZn}$ フェライトのレーザ加工 -加工雾囲気の影響- \\ Laser Processing of Single Crystal MnZn Ferrite -Effect of processing atmosphere on processing capability- \\ 学 長三男 (千葉工業大学)

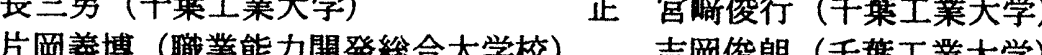 \\ 正 三須直志（千葉工業大学）
}

Mitsuo CHO, Chiba Institute of Technology, 2-17-1, Tsudanuma, Narashino, Chiba Toshiyuki MIYAZAKI/Chiba Institute of Technology Yoshihiro KATAOKA/ Polytechnic University Shunro YOSHIOKA/ Chiba Institute of Technology Tadashi MISU/ Chiba Institute of Technology

Key Words: MnZn ferrite, Pulsed laser, Single crystal

\section{1.はじめに}

単結晶 $\mathrm{MnZn}$ フェライトは，磁気素子して広く用いられ ている. 通常，成形加工には砥粒加工を用いる，砥粒加工 は治具によって加工物の寸法が左右される。また加工の自 由度も制限される. そのため小型化の進む電子機器の部品 の微細な加工は難しい。

本研究ではレーザ加工の微細加工への適用を検討した。 $\mathrm{MnZn}$ フェライトは脆性材料であるため熱応力により割れ 易い．そのため熱拡散の少ない短パルスレーザを用いた. また，加工㞣用気を酸とアルカリの 2 種のエッチング溶液 を用いレーザ援用エッチング加工も検討した。

\section{2. 実験}

試料は, 単結晶 $\mathrm{MnZn}$ フェライト(MnO:30 mol\%, $\mathrm{ZnO}: 10$ $\left.\mathrm{mol} \%, \mathrm{Fe}_{2} \mathrm{O}_{3}: 60 \mathrm{~mol} \%\right)$ を(110)面に平行に切り出して成形 した。試料は表面を平坦とするために，りん酸でエッチン グした. 加工は(110)面に行った

レーザはパルス Nd: YAG レーザ(4 倍高調波，波長 $266 \mathrm{~nm})$, パルス幅 6ns, エネルギー2.3mJ/パルスである. Fig.1 に実 ルを用い，微細寸法のレーザビームを用いた。

実験はレーザの照射回数と加工㞣囲気を大気中， $\mathrm{H}_{2} \mathrm{O}$, $\mathrm{KOH}$ 溶液, $\mathrm{H}_{3} \mathrm{PO}_{4}$ 溶液と変化させて行った。 $\mathrm{KOH}$ 溶液, $\mathrm{H}_{3} \mathrm{PO}_{4}$ 溶液はそれぞれ $1.5 \mathrm{~mol} / \mathrm{l}, 3 \mathrm{~mol} / 1,6 \mathrm{~mol} / 1$, につい て検討した，溶液面から陚料表面までの距雄は $1 \mathrm{~mm}$ とし た.レーザのパルス繰り返し周波数は $2 \mathrm{~Hz}$ ，パワー密度は $1 \times 10^{8} \mathrm{~W} / \mathrm{cm}^{2}$ とした.

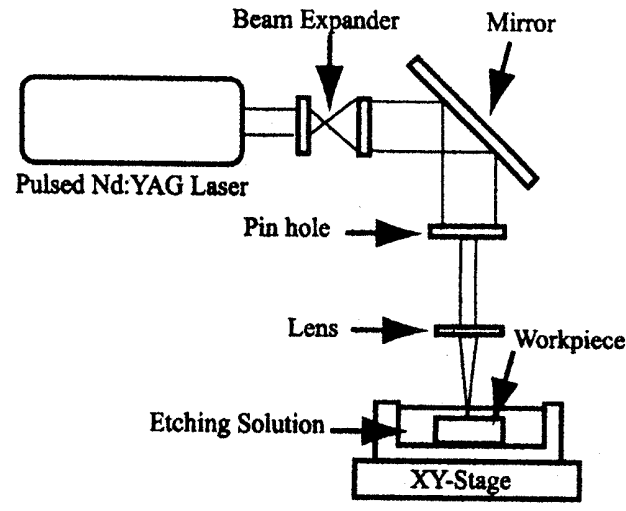

Fig.1 Experimental equipment

\section{3. 実験結果}

3. 1 加工㞣囲気の比較

SEM を用いて加工部を観察をした. Fig.2 に各種条件に よる SEM 画像を示す，大気中では加工穴の周囲にダメー ジが見られるが溶液中では見られない。これはビ一ム外縍 のパワーの弱いところが溶液に吸収されたためと思われる. Fig.3 に照射回数と加工深さを示す.大気, $\mathrm{KOH}(1.5 \mathrm{~mol} / \mathrm{l})$, $\mathrm{H}_{3} \mathrm{PO}_{4}(1.5 \mathrm{~mol} / \mathrm{l})$, 水中の順で浅くなっていっている. Fig.2 に示す条件では照射回数を増やしてもクラックは生じない.

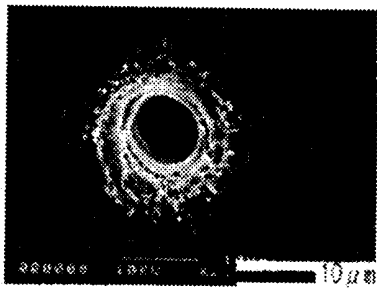

(a) Air

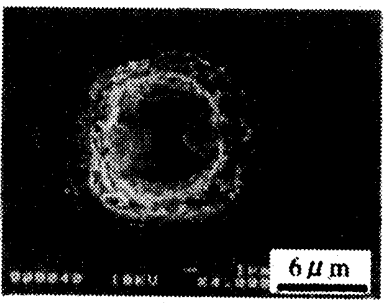

(c) $\mathrm{KOH}: 1.5 \mathrm{~mol} / 1$

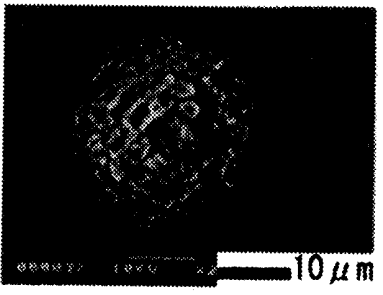

(b) Water

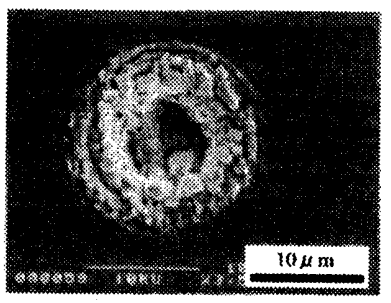

(d) $\mathrm{H}_{3} \mathrm{PO}_{4}: 1.5 \mathrm{~mol} / 1$
Fig. 2 Laser processed area

(Power density $1 \times 10^{8} \mathrm{~W} / \mathrm{cm}^{2}$,

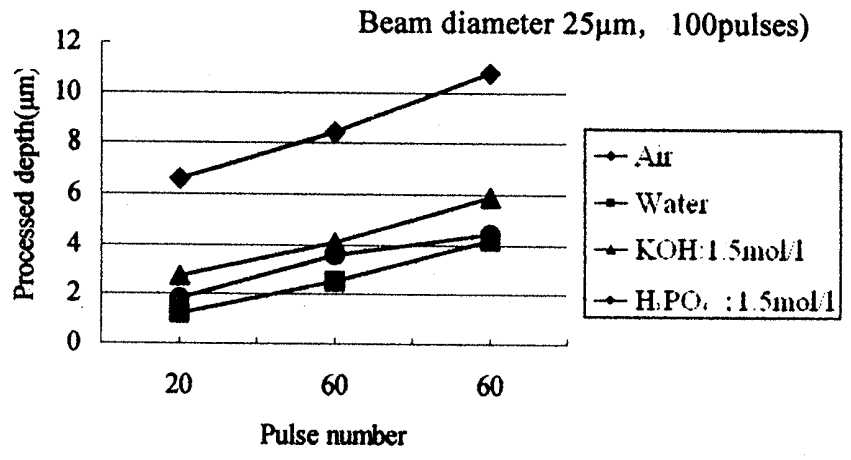

Fig.3 Pulse number and processed depth

(Power density $1 \times 10^{8} \mathrm{~W} / \mathrm{cm}^{2}$, Beam diameter $25 \mu \mathrm{m}$ )

日本機械学会 $[$ №.037-1］北陸信越支部 第40期総会・講演会論文集 [2003.3.15，福井市］ 
3. 2 溶液濃度と加工特性

溶液の浱度を $3 \mathrm{~mol} / \mathrm{l}, 6 \mathrm{~mol} / \mathrm{l}$ として加工穴を観察した。 Fig.4 に各溶液の浱度と加工染さの関係を示す. 灌度 $0 \mathrm{~mol} / 1$ は水中加工である. 照射回数が増えると加工は深くなる. 加工骞囲気が $\mathrm{KOH}$ の場合, 灌度が上がると浅くなる. 加 工察囲気が $\mathrm{H}_{3} \mathrm{PO}_{4}$ では $3 \mathrm{~mol} / 1$ が他に比べて染くなった。 2 つの容液を通して，最も梁く加工できたのは KOH : 6 mol/1 であった。
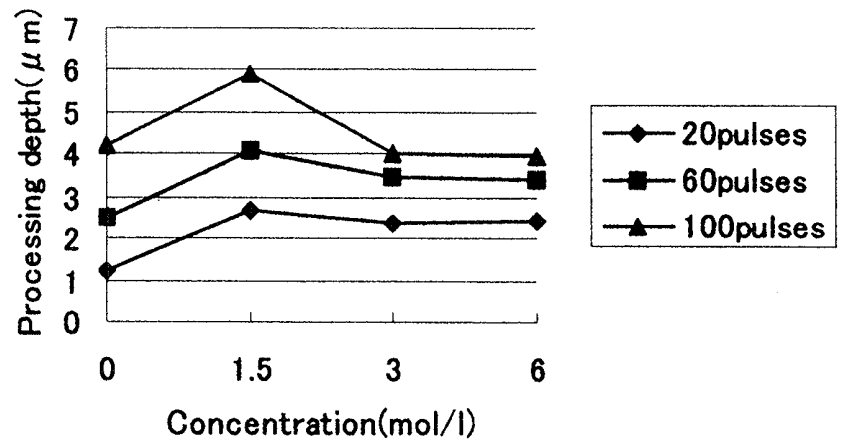

(a) $\mathrm{KOH}$

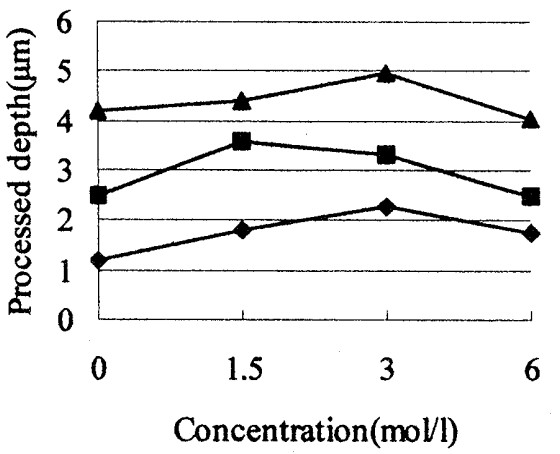

(b) $\mathrm{H}_{3} \mathrm{PO}_{4}$

Fig. 4 Concentration and processed depth (Power density $1 \times 10^{8} \mathrm{~W} / \mathrm{cm}^{2}$, Beam diameter $25 \mu \mathrm{m}$ )

加工部を SEM により钼察すると,Fig.5(a), (b)に示すよう

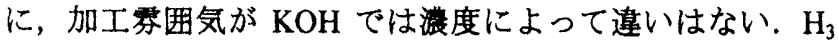
$\mathrm{PO}_{4}: 6 \mathrm{~mol} / 1$ 以外は Fig. 5 (a), (b), (c)の様にかさぶた状のパ ターンが見える. Fig. 5 (d) $\mathrm{H}_{3} \mathrm{PO}_{4}: 6 \mathrm{~mol} / 1$ ではエッチングの 様な滑らかな加工痕が見られた．加工穴輸郭にはクラック の発生がある．照射回数が増えても同様である。

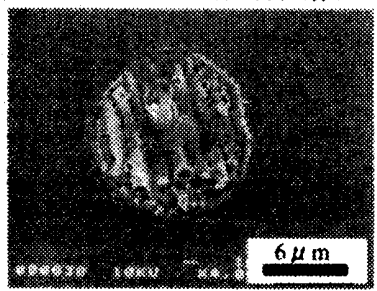

(a) $\mathrm{KOH}: 1.5 \mathrm{~mol} / 1$

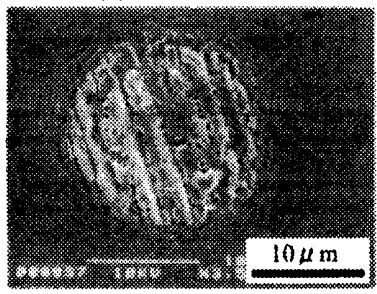

(c) $\mathrm{H}_{3} \mathrm{PO}_{4}: 1.5 \mathrm{~mol} / \mathrm{l}$

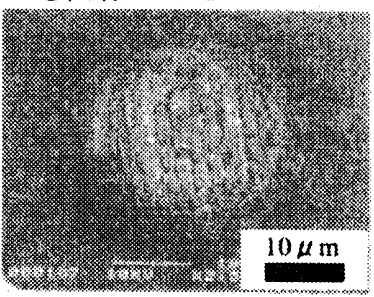

(b) $\mathrm{KOH}: 6 \mathrm{~mol} / 1$

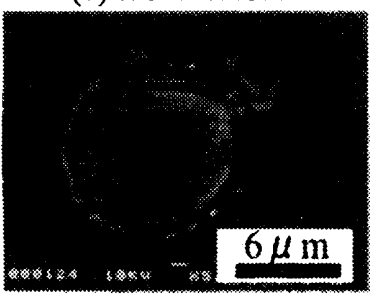

(d) $\mathrm{H}_{3} \mathrm{PO}_{4}: 6 \mathrm{~mol} / 1$
Fig. 5 Laser processed area

(Power density $1 \times 10^{8} \mathrm{~W} / \mathrm{cm}^{2}$,

Beam diameter $25 \mu \mathrm{m}, 20 \mathrm{pulses})$
加工幅を Fig.6 に示す. 灌度 $0 \mathrm{~mol} / 1$ は水中加工である. 加工等囲気が $\mathrm{KOH}$ では，湦度が上がると加工幅が広がり， 逆に $\mathrm{H}_{3} \mathrm{PO}_{4}$ では瀑度が下がると加工幅が狭くなった。照射 回数が增えても 2 つ溶液の加工幅に変化が見られない，

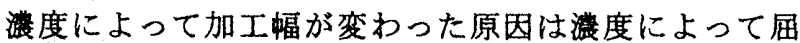
折率が変化したためと考えられる。
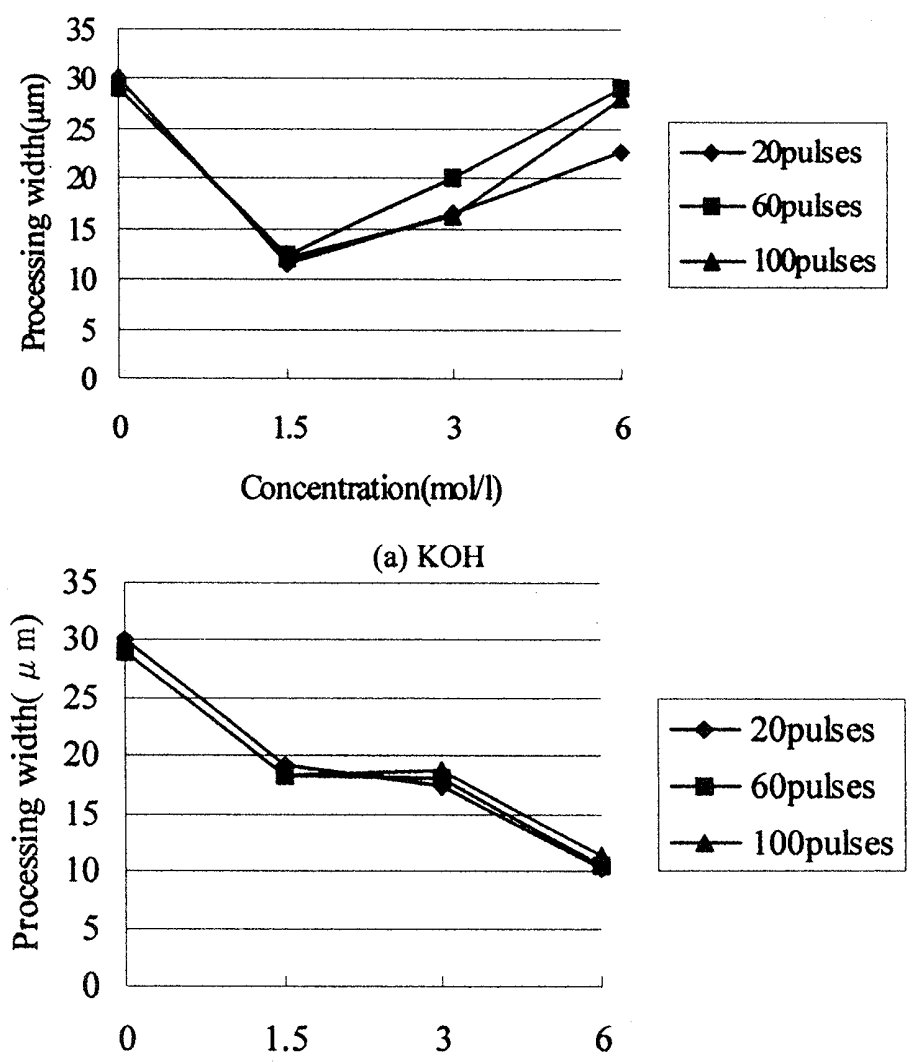

Concentration $(\mu \mathrm{m})$

(b) $\mathrm{H}_{3} \mathrm{PO}_{4}$

Fig. 6 Concentration and processed width (Power density $1 \times 10^{8} \mathrm{~W} / \mathrm{cm}^{2}$, beam diameter $25 \mu \mathrm{m}$ )

4. まとめ

単結晶 $\mathrm{MnZn}$ フェライトを波長 $266 \mathrm{~nm}$ ，パルス幅 $6 \mathrm{ns，}$ パルス綕り返し周波数 $2 \mathrm{~Hz}$, ビーム直径 $25 \mu \mathrm{m}$ ，パワー密 度 $1 \times 10^{8} \mathrm{~W} / \mathrm{cm}^{2}$ のレーザビームで加工した，加工骞囲気を 水, $\mathrm{KOH}$ 溶液, $\mathrm{H}_{3} \mathrm{PO}_{4}$ 溶液とすると,加工部の深さ, 幅が 変化がした。

また, $\mathrm{H}_{3} \mathrm{PO}_{4}: 6 \mathrm{~mol} / 1$ の溶液を用いた加工では，表面形状 滑らかになることが分かった。

\section{参考文献}

1) 宮畹俊行他; 精密工学会, 春季大会講演論文集(2001), 117.

2)長 三男他; 精密工学会, 春季大会講演論文集 $(2002), 380$. 3)長 三男他; 日本機械学会, 東北支部講演会講演予稿集 (2002), 192. 